\title{
A Response to Shabbir A. Abbas' Review of The Words of God to Prophet Muhammad
}

John Andrew Morrow

Shabbir A. Abbas, a graduate student from Rutgers University, completed a thorough and thoughtful review of my work, The Words of God to Prophet Muhammad: Forty Sacred Sayings, in the American Journal of Islamic Socials Sciences 34, no. 2 (spring 2017): 102-04.

Abbas provides relevant biographical and bibliographical information about Sayyid Hasan Shirazi, the compiler of Kalimat Allāh from which I drew the Forty Hadith and presented in Arabic along with my English translation. I am pleased that the reviewer described my translation as "refreshingly accurate... and ... perfectly intelligible." I am also honored that he described my preface as "excellent."

Although I agree with most of what Abbas has to say, I object to one statement. According to him, my "decision not to provide the isnād or even a citation of the translated ahadīth renders them academically unfit. Hasan Shirazi provided such information" (p. 103). This is factually incorrect. While Shirazi does include the chains of transmission when they are avail- 
able, the Forty Hadith in question have been transmitted without them. Some novices might argue that this is a sign of forgery; however, hadith scholars are well-aware that the oldest books of traditions were transmitted without them. Take, for example, a work such as Tuhaf al- 'Uqūl by al-Harrani, to cite but one example. Since I explicitly addressed this issue in the preface and noted that the Dar al-Hadith Institute in Qum confirmed that the Forty Traditions are devoid of chains of narration, this fact should not have been brought up as a shortcoming in the review.

The claim that the preface, translation, and commentary are disharmonious has some validity. If the objective of the book is spiritual, argues Abbas, then the preface is "too academic for laypeople to understand," "the commentaries prolong the work unnecessarily," and "the [Arabic] font promotes reader fatigue" (p. 103).

Fortunately, his suggestions arrived shortly before the work's publication in French/Arabic and Spanish/Arabic. Although I have maintained the preface, which I believe is necessary to introduce the work to educated readers, I have suppressed the commentaries by Charles Upton not because they lack value and spiritual insight, but because they make the short, pious work too long for lay readers. I have also specifically asked the publisher to use a larger, more appealing, Arabic script - one that will be easy on the eyes.

The works in question, Les paroles d'Allah au Prophète Muhammad: Quarante traditions sacrées and Las palabras de Allāh al Profeta Muhammad: cuarenta dichos sagrados, are set to be published by Dar al-Kutub al-'Ilmiyyah, in Beirut, in the months to come. These works should be of interest to French- and Spanish-speaking scholars in the field. 